\title{
Relationship of testosterone pulses to androgen binding in the pituitary of rams
}

\author{
J. Pelletier, M. Terqui and M. L. Thieulant*
}

Institut National de la Recherche Agronomique, Station de Physiologie de la Reproduction, 37380 Nouzilly and ${ }^{*}$ Laboratoire de Biochimie générale, Faculté des Sciences, Campus de Beaulieu, 35042 Rennes Cedex,

France

\begin{abstract}
Summary. The effects of testosterone on cytosol and nuclear androgen receptors of ram pituitary were examined in two experiments. In Exp. I, $500 \mu \mathrm{g}$ testosterone were injected intravenously and groups of 4 rams were slaughtered at $0,15,30,45,90$ and 360 min after injection. Cytosolic receptor concentration decreased from $21 \pm 0.9$ to $6 \pm 0.9 \mathrm{fmol} / \mathrm{mg}$ protein $30 \mathrm{~min}$ after the testosterone injection $(P<0.001)$, and then returned towards the preinjection level after $90 \mathrm{~min}$. The pattern of nuclear receptor concentration was the opposite; a maximal increase $(12 \pm 3.5$ to $32 \pm 5.7 \mathrm{fmol} / \mathrm{mg}$ protein) was observed $30 \mathrm{~min}$ after injection $(P<0.001)$, followed by a progressive but incomplete decrease by $360 \mathrm{~min}$. In Exp. II, blood was collected every $20 \mathrm{~min}$ for $17 \mathrm{~h}$ in three successive series, each of 12 rams, which were then slaughtered. Plasma LH and testosterone concentrations were measured by radioimmunoassay. No changes were observed in cytosol receptor concentration, but nuclear receptor concentration was negatively correlated with the interval elapsed since the beginning of the last testosterone pulse $(r=-0.62 ; P<0.001)$. The highest values for nuclear receptor concentrations were observed at an interval equal to or less than $120 \mathrm{~min}$. These results indicate that natural pulses are associated with androgen binding particularly in the pituitary nuclei.
\end{abstract}

\section{Introduction}

A causal relationship between $\mathrm{LH}$ and testosterone pulses in the plasma of rams has been demonstrated in a number of studies (Pelletier, Garnier, de Reviers, Terqui \& Ortavant, 1982). On the other hand, the potential feedback effect of one natural pulse of testosterone has never been demonstrated in any animal species. In rams, we postulated a double feedback effect of testosterone at the hypothalamic and pituitary levels (Pelletier, 1970, 1974), an assumption which has been substantiated by D'Occhio, Schanbacher \& Kinder (1982). However, the experimental protocols in these different studies involved the administration of testosterone in pharmacological doses or in non-physiological circumstances. The existence of androgen-specific receptors in the cytosol of the ram pituitary suggests that under natural conditions these steroids might act directly (Thieulant \& Pelletier, 1979). The present study was undertaken to examine whether androgen binding to the pituitary occurs in the ram after exogenous testosterone injection and after endogenous testosterone pulses.

\section{Materials and Methods}

Animals. Seventy-two Ile-de-France rams were used, ranging in age between 2 and 5 years. Twelve intact or castrated rams were slaughtered at different times to establish optimal conditions for 
determination of nuclear binding of $\left[{ }^{3} \mathrm{H}\right]$ dihydrotestosterone (see below). The anterior pituitary was collected immediately after decapitation and processed at once or frozen in liquid nitrogen and processed the next day.

Experiment I. During March, at the time of sexual inactivity, intact rams received an intravenous injection of $500 \mu \mathrm{g}$ testosterone in $10 \mathrm{ml}$ saline $\left(0 \cdot 2 \mathrm{M}-\mathrm{NaCl}, \mathrm{I} \cdot 9 \mathrm{mM}-\mathrm{NaH}_{2} \mathrm{PO}_{4} \cdot 1 \mathrm{H}_{2} \mathrm{O}\right.$, $\left.8.0 \mathrm{mM}-\mathrm{Na}_{2} \mathrm{HPO}_{4}\right)$ containing $8 \%$ ethanol $(20 \mathrm{rams})$ or vehicle only (4 control rams). Four testosterone-treated rams were slaughtered at $15,30,45,90$ and $360 \min \left(\mathrm{T}_{15}\right.$ to $\left.\mathrm{T}_{360}\right)$ after injection. Control rams were slaughtered immediately after the saline injection $\left(T_{0}\right)$. Blood samples were collected from all animals just before injection and at slaughter. In addition, blood samples were collected at $15 \mathrm{~min}$ from the rams slaughtered at $T_{30}$, at 15 and $30 \mathrm{~min}$ from those slaughtered at $\mathrm{T}_{45}$ and at $90 \mathrm{~min}$ and $5 \mathrm{~h}$ from those slaughtered at $\mathrm{T}_{360}$. Plasma was frozen until hormone assay. The anterior pituitary was cut in half and frozen in liquid nitrogen for measurements of cytosolic and nuclear receptors.

Experiment II. Between January and March, blood from three series of 12 intact rams was collected from the jugular vein every $20 \mathrm{~min}$ for $17 \mathrm{~h}$, after which one ram was slaughtered every $15 \mathrm{~min}$. The pituitary was processed as in Exp. I.

The time-course between the onset of the last testosterone pulse and slaughter was then correlated with the level of nuclear receptors. The beginning of the last pulse was defined as the first sample within the pulse with a level higher than the mean basal level +2 s.d. (see Text-fig. 2a). When the last two pulses were closely related (Text-fig. 2b), the interval between the time of the first rise after the nadir of testosterone concentration and slaughter was used. In all cases, the beginning of a testosterone pulse was checked against the presence of a previous LH pulse.

Chemicals. $\left[1,2-{ }^{3} \mathrm{H}\right] 5 \alpha$-Dihydrotestosterone (sp. act. $60 \mathrm{Ci} / \mathrm{mmol}$ ) was obtained from the Radiochemical Centre (Amersham, Bucks, U.K.). Unlabelled steroids were obtained from Sigma Chemical Co (St Louis, MO, U.S.A.). All reagents were of analytical grade.

Cytosol receptor assay. This assay was performed according to a procedure previously described for the ram pituitary (Thieulant \& Pelletier, 1979). Briefly, pituitary halves were individually homogenized in phosphate buffer $(10 \%$, w/v) and centrifuged at $800 \mathrm{~g}$ for $10 \mathrm{~min}$; the supernatant was recentrifuged at $105000 \mathrm{~g}$ for $1 \mathrm{~h}$. The cytosols, diluted to $100-200 \mu \mathrm{g}$ protein $/ 100 \mu \mathrm{l}$, were incubated for $2 \mathrm{~h}$ at $0^{\circ} \mathrm{C}$ with increasing levels $\left(0.04-2.57 \times 10^{-9} \mathrm{M}\right)$ of $\left[{ }^{3} \mathrm{H}\right] \mathrm{DHT}$ in the presence (blank tubes) or absence of 100 -fold excess of unlabelled DHT. ${ }^{3} \mathrm{H}$-Bound and free steroids were separated by precipitation with protamine sulphate (Blondeau, Corpechot, Le Goascogne, Baulieu \& Robel, 1975). The washed precipitate was dissolved into $10 \mathrm{ml}$ scintillant and radioactivity was counted. The whole procedure was carried out at $0-4^{\circ} \mathrm{C}$. DHT was used to measure the testosterone receptor since only one androgen receptor has been found in the pituitary in rams and since DHT has a slightly higher affinity for the receptor than testosterone (Thieulant \& Pelletier, 1979).

Preparation of purified nuclei. Nuclei were isolated by a slight modification of the method of Widnell \& Tata (1964). All procedures were performed at $0-4^{\circ} \mathrm{C}$. Pituitary halves were finely minced and homogenized in 4 volumes $(\mathrm{v} / \mathrm{v})$ of Medium $\mathrm{A}\left(0.32 \mathrm{M}\right.$-sucrose, $3 \mathrm{mM}-\mathrm{MgCl}_{2}$ and $\left.1 \mathrm{mM}-\mathrm{KH}_{2} \mathrm{PO}_{4}, \mathrm{pH} 6.5\right)$. After the homogenate had been diluted with Medium A (v/v) and distilled water to a final concentration of $0.25 \mathrm{M}$-sucrose, the suspension was carefully layered over 5 volumes of Medium A and centrifuged at $1000 \mathrm{~g}$ for $10 \mathrm{~min}$. The pellet was resuspended in $0.6 \mathrm{ml}$ Medium A, rehomogenized and diluted in 4 volumes of Medium B (2.4 M-sucrose, $1 \mathrm{mM}-\mathrm{MgCl}_{2}$, $1 \mathrm{mM}-\mathrm{KH}_{2} \mathrm{PO}_{4}, \mathrm{pH} 6 \cdot 5$ ). The tubes were centrifuged at $53500 \mathrm{~g}$ for $60 \mathrm{~min}$. The pellet was identified as purified nuclei and immediately extracted. In pellets checked for purity by electron microscopy, the nuclei appeared intact and free of cytoplasmic contaminants. 
Nuclear extracts. According to the technique of Roy \& McEwen (1977) TDB buffer (10 mM-Tris, I mM-dithiothreitol and $0.5 \mathrm{~mm}$-bacitracin, $\mathrm{pH} 7.4$ ) was added to the nuclear pellet to a final concentration of $0.50 \mathrm{ml} / 0.50 \mathrm{~g}$ pituitary gland. The suspension was dispersed by gentle magnetic stirring for $1 \mathrm{~min}$ and then diluted with $\mathrm{NaCl}$-TDB buffer to a final concentration of $0.6 \mathrm{M}-\mathrm{NaCl}$. The tube was submitted to moderate magnetic stirring overnight, after which the extract was diluted to a final $\mathrm{NaCl}$ concentration of $0.3 \mathrm{M}$ with TDB buffer and centrifuged at $40000 \mathrm{~g}$ for $10 \mathrm{~min}$. The supernatant is referred to as the nuclear extract; the DNA was precipitated without trapping of ${ }^{3} \mathrm{H}$-bound steroid (Zava, Harrington \& McGuire, 1976).

Nuclear receptor assay. We used a multiple saturation dose assay. Samples of the nuclear extracts $(100-200 \mu \mathrm{g}$ protein $/ 0 \cdot 2 \mathrm{ml})$ were incubated with $6-60 \mathrm{nM}-\left[{ }^{3} \mathrm{H}\right] \mathrm{DHT}$ overnight $(16-20 \mathrm{~h})$ at $0-4^{\circ} \mathrm{C}$ in the presence or absence of a 100 -fold excess of non-radioactive DHT. Preliminary studies had indicated that $\left[{ }^{3} \mathrm{H}\right] \mathrm{DHT}$ binding reached plateau levels at that time. Specific binding was determined using the protamine sulphate assay (Blondeau et al., 1975) after the $0.3 \mathrm{M}$ nuclear extract had been diluted to a final concentration of $0.15 \mathrm{M}-\mathrm{NaCl}$ with $\mathrm{TDB}$ buffer; higher concentrations have been shown to interfere with the assay (Zava et al., 1976).

Evaluation of possible metabolic degradation of $\left[{ }^{3} \mathrm{H}\right] \mathrm{DHT}$ during incubation. After incubation with $20 \mathrm{nM}-\left[{ }^{3} \mathrm{H}\right] \mathrm{DHT}$ for $20 \mathrm{~h}$, the nuclear extracts were precipitated with protamine sulphate and filtered on Whatman GF/C filters. The filters were then extracted three times with methylene dichloride and the extracted steroids were chromatographed on thin-layer alumina gel plates using benzene-ethanol $(20 / 1, v / v)$ (Corker, Exley \& Naftolin, 1970). At the end of incubation, chromatographic analysis indicated that $74 \%$ of the $\left[{ }^{3} \mathrm{H}\right] \mathrm{DHT}$ was unchanged. The $\left[{ }^{3} \mathrm{H}\right] \mathrm{DHT}$ did not therefore appear to be extensively metabolized in the $\mathrm{NaCl}$ nuclear extracts. In a previous study (Thieulant \& Pelletier, 1979), we had found that $91 \%$ of the $\left[{ }^{3} \mathrm{H}\right] \mathrm{DHT}$ in cytosol was unchanged after incubation.

Protein measurements. The protein concentration in cytosolic or nuclear extract was determined by the Coomassie brilliant blue G-250 binding method of Bradford (1976) or that of Lowry, Rosebrough, Farr \& Randall (1951). Cytosol receptor number, computed according to Scatchard (1949), and nuclear receptor number, obtained from the specific saturation curve, were expressed as $\mathrm{fmol} / \mathrm{mg}$ protein.

Radioimmunoassays of $\mathrm{LH}$ and testosterone. Plasma $\mathrm{LH}$ was measured according to Pelletier, Kann, Dolais \& Rosselin (1968) with the modifications indicated by Pelletier et al. (1982). Sensitivity was $0.1 \mathrm{ng} / \mathrm{ml}$ and the within assay coefficient of variation was $3 \%$. LH-M3 $(=1 \cdot 8$ NIH-LH-S1) was used as standard.

Plasma testosterone was measured without extraction according to the method described by Garnier, Cotta \& Terqui (1978); assay sensitivity was $0.2 \mathrm{ng} / \mathrm{ml}$. The within-assay coefficient of variation was about $8 \%$ for 1 and $5 \mathrm{ng} / \mathrm{ml}$.

Statistical analysis. The data were analysed by analysis of variance and Student's $t$ test. The results are presented as the mean \pm s.e.m.

\section{Results}

\section{Experiment I}

The different groups of rams appeared homogeneous when the analysis of variance was applied to carcass weight (range: $34-38.5 \mathrm{~kg}$ ), pituitary weight (range $1.0-1.3 \mathrm{~g}$ ) and testicular weight (range $150-175 \mathrm{~g})$.

At $\mathrm{T}_{0}$, just before injection, the mean level of plasma testosterone was $1.5 \pm 0.46 \mathrm{ng} / \mathrm{ml}$ $(\mathrm{N}=24)$; only one ram in the group slaughtered at $\mathrm{T}_{360}$ showed a higher value than the mean +2 s.d. and was thus considered as having had a testosterone pulse. Text-figure 1(a) depicts 


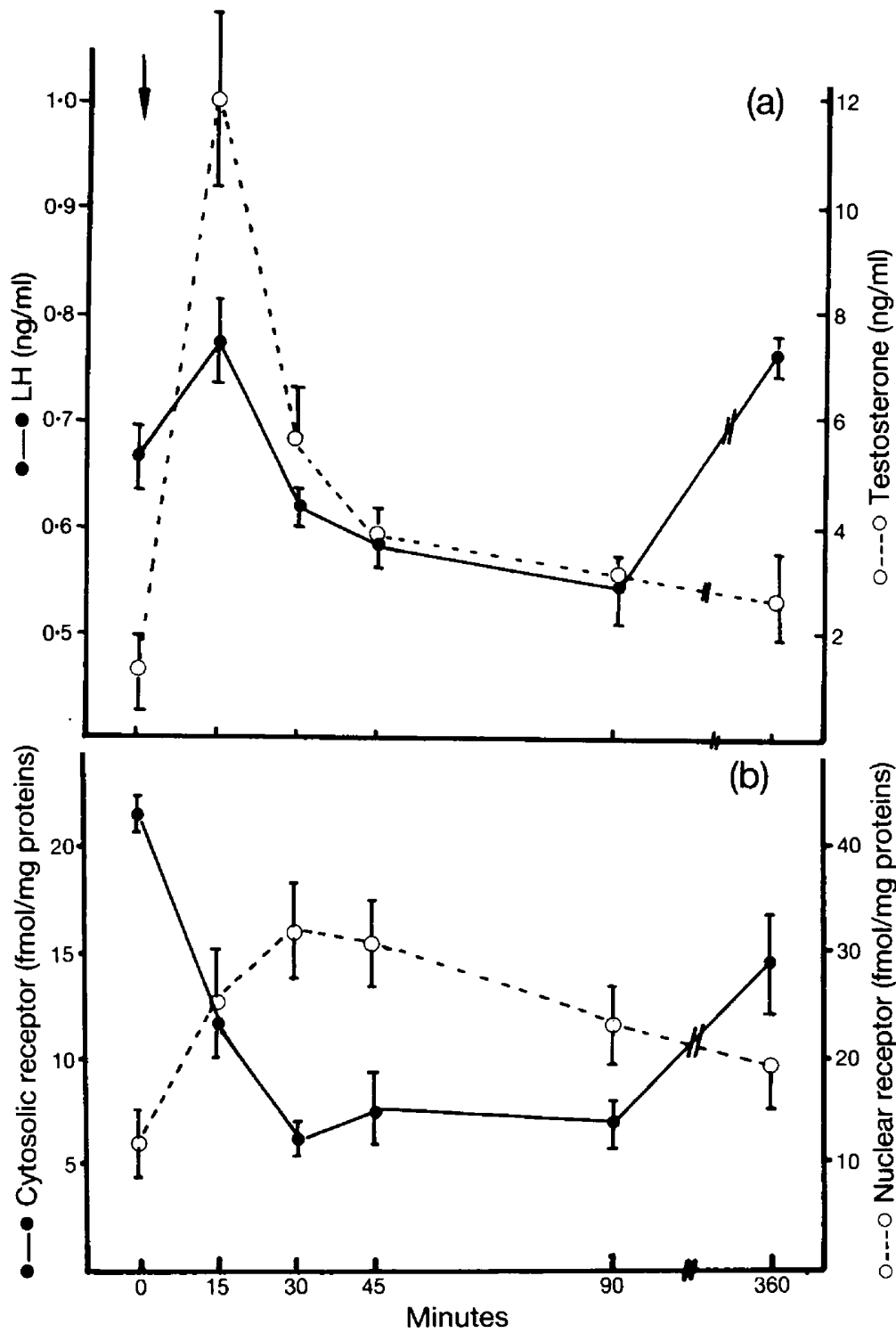

Text-fig. 1. Plasma LH and testosterone concentrations (a) and cytosolic ( -0$)$ and nuclear $(\mathrm{O}-\mathrm{O})$ receptor concentrations in the pituitary (b) of rams after intravenous injection of $500 \mu \mathrm{g}$ testosterone $(\downarrow)$ in Exp. I. Each point represents the mean \pm s.e.m. values for 4 rams slaughtered at time shown on the abscissa.

the changes in plasma testosterone concentrations before $\left(\mathrm{T}_{0}\right)$ and after the injection of $500 \mu \mathrm{g}$ testosterone at the time of the slaughter of the different groups. After testosterone injection, plasma concentration was about 9 times higher at $T_{15}$ than at $T_{0}(P<0.02)$. It then declined abruptly, the difference being non-significant $45 \mathrm{~min}$ after injection. The pattern was not different when the other blood samples taken at various times were considered (see 'Materials and Methods').

The mean preinjection level of plasma LH $(\mathrm{N}=4)$ was $0.66 \pm 0.051 \mathrm{ng} / \mathrm{ml}$. Only the ram previously recorded as having a testosterone pulse showed a higher value at that time than the mean +2 s.d. No significant variations in piasma $\mathbf{L H}$ were recorded after testosterone injection (Text-fig. 1a). 
Concomitant variation in cytosolic and nuclear DHT receptors in the pituitary after testosterone administration are shown in Text-fig. 1(b). Analysis of variance showed that both varied significantly between groups $(P<0.001)$. Compared to the $\mathrm{T}_{0}$ values, cytosolic receptor concentrations were signficantly less at $\mathrm{T}_{15}(P<0.01)$ and $\mathrm{T}_{30}(P<0.001)$ and then plateaued between $T_{30}$ and $T_{90}$. A partial return to the $T_{0}$ value was observed 360 min after injection. The pattern of variations in nuclear receptor concentrations was the mirror image of that observed for the cytosolic receptor. Values were significantly higher than at $T_{0}$ from 15 to $90 \mathrm{~min}$ after the testosterone injection $\left(P<0.001\right.$ at $\left.\mathrm{T}_{30}\right)$. After $360 \mathrm{~min}$, the concentration of nuclear receptors was still slightly higher than the preinjection value $(P<0.05)$. The results were essentially identical when expressed as the receptor content of the total gland for both cytosolic and nuclear receptors. Similarly, the sum of cytosolic plus nuclear receptors per pituitary did not vary significantly with the time after the testosterone injection.

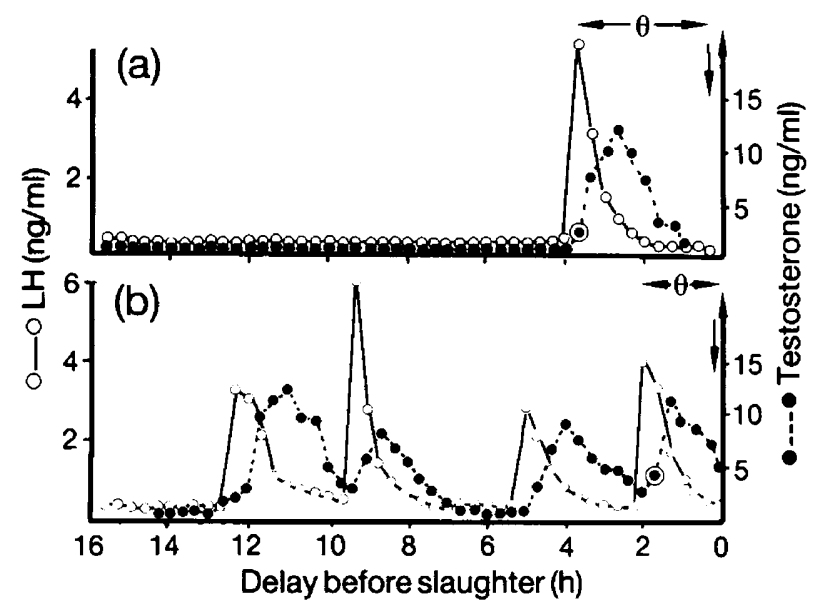

Text-fig. 2. LH and testosterone pulses in the blood of representative rams (a \& b) collected every $20 \mathrm{~min}$ for $17 \mathrm{~h}$ before slaughter in Exp. II. The interval $(\theta)$ between the beginning of the last pulse $(\odot)$ and slaughter $(\downarrow)$ was correlated with the amount of nuclear receptor.

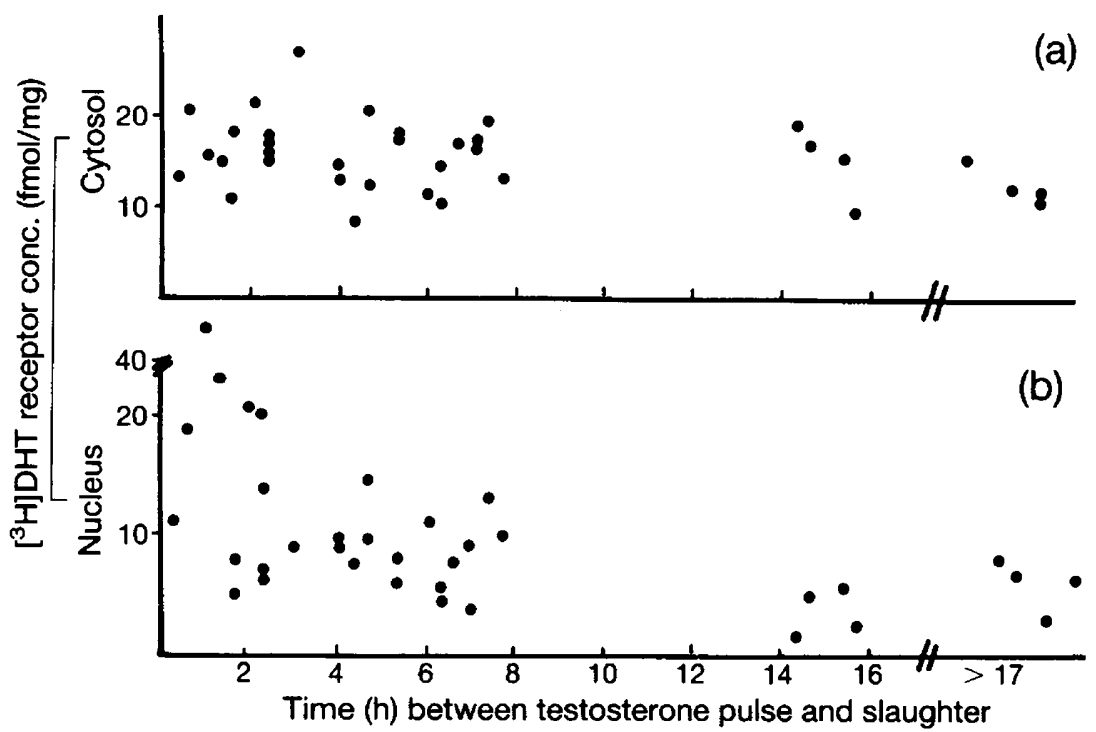

Text-fig. 3. Cytosolic (a) and nuclear (b) receptor concentrations as a function of the time between the last testosterone pulse and slaughter in Exp. II. 


\section{Experiment II}

The three groups of 12 rams each did not differ in carcass weight, pituitary weight or testicular weight and so the values were pooled.

By analysis of the blood collected, 31 out of 36 rams showed at least one testosterone pulse, preceded in all cases by an LH pulse (Text-fig. 2). Four animals showed no pulse of LH or testosterone. The status of one ram was uncertain since at the last bleeding it showed a modest but not significant increase in both $\mathrm{LH}$ and testosterone concentrations. Of the 31 rams, 23 showed 1-2 pulses within the whole profile; 6 others had 3-5 pulses, one animal had 7 and another had 10: The numbers of rams, pooled per hour, as a function of the interval between last testosterone pulse and slaughter, were not equally distributed since 27 intervals ranked between 1 and $8 \mathrm{~h}$ and four between 14 and $16 \mathrm{~h}$.

The individual values of receptor concentration in cytosol (Text-fig. 3a) or in the nucleus (Textfig. 3b) were calculated as a function of the 'testosterone pulse to slaughter' interval. Cytosolic receptor levels (expressed in concentration or total content per pituitary) did not change when the interval increased, but there was a rapid increase of nuclear receptors, followed by a progressive decrease. Considering all the 31 values for which an interval had been defined and after exponential fitting, nuclear receptor concentration was negatively correlated with the interval from the last pulse $(r=-0.62 ; P<0.001)$.

The model of receptor variation in the nuclei after administration of testosterone normally indicates an initial increase before exponential decay as in Exp. I. However, in the present case, only one ram had an interval of $20 \mathrm{~min}$ which might be considered to be in the ascending part of the curve. Discarding the corresponding value in computing the correlation coefficient did not significantly modify the $r$ value $(r=-0.66)$. The correlation was also found to be significant if the total nuclear receptor content per pituitary was considered $(r=-0.48 ; P<0.001)$. By using the time of the testosterone peak value instead of the onset of the pulse to define the interval to slaughter, the correlation coefficient was also highly significant $(r=-0.58 ; P<0.001)$. In addition the nuclear receptor concentration was correlated positively with the plasma testosterone concentration at slaughter $(r=+0.51 ; P<0.001)$.

\section{Discussion}

In the first experiment, a very moderate dose of testosterone was injected (about $6 \mu \mathrm{g} / \mathrm{kg}$ body weight) to simulate the conditions of a natural pulse. At 15 min after injection, plasma testosterone concentration in the jugular vein was close to the peak value attained in a natural pulse estimated by continuous blood collection (Terqui, Garnier, de Reviers, Huet \& Pelletier, 1980). However, the levels (not measured) attained during the first minutes following injection were probably supraphysiological. After the testosterone injection, receptor variations were comparable to those normally observed in target tissue after a steroid injection, i.e. a temporary decrease in cytosolic receptors and a parallel transient increase in nuclear receptors (see Clark \& Peck, 1979). The injection of $100 \mu \mathrm{g}$ oestradiol in ewes induced variations of both types of recpetors similar to those observed in the present study (Clarke, Funder \& Findlay, 1982). Furthermore, the results of Exp. I show that nuclear binding was maximal shortly $(30 \mathrm{~min})$ after the steroid injection. One endogenous pulse of $\mathrm{LH}$ and of testosterone was seen in one ram slaughtered $6 \mathrm{~h}$ later. No other pulses were detected and so their occurrence can be considered here as having a negligible effect on the results. The results of Exp. I thus validated the methodology used for receptor measurement and allowed further analysis under natural conditions.

In Exp. II, coupled LH and testosterone pulses were found in 31 out of 36 rams. The 'beginning of the last pulse-to-slaughter' interval was chosen in the light of the early peak in nuclear binding shown in Exp. I. The uncertainty about the beginning of the testosterone pulse, when there are multiple pulses within a profile, has only a slight influence on the conclusions. Furthermore, the 
correlation coefficient is not different when the peak testosterone value is taken into account instead of the beginning of the pulse.

The reasons why there are no major changes in cytosolic receptors after a natural pulse are not clear. Receptor measurements were carried out under strictly identical conditions in Exp. I and II, but the absence of variation might be related to the less acute testosterone release during a natural pulse compared to a bolus administration. The exact status of cytosol receptors has been questioned in the works of Welshons, Lieberman \& Gorski (1984) and King \& Greene (1984), leading to the conclusion that this compartmentalization might be artefactual.

The results of Exp. II indicate that the magnitude of binding may be related to the time from the beginning of the last testosterone pulse, the highest values of nuclear binding being found for intervals of 0 to $120 \mathrm{~min}$. Attempts to correlate cytosolic and nuclear receptor concentrations with the quantity of testosterone released during the last pulse (the area under the curve) or during the whole profile were unsuccessful. The short time of nuclear binding (Exp. I) could explain the absence of such a relationship in Exp. II.

Taken collectively, the results of nuclear binding measurement in Exp. II indicate that under natural conditions each pulse of testosterone constitutes a message to the pituitary although the exact nature of the message transmitted by an individual pulse is unknown. This message is not mediated via androgen aromatization since no changes in oestradiol nuclear receptors were observed after the testosterone pulse (unpublished results).

The plasma LH concentrations did not vary in Exp. I following the testosterone injection in spite of clear changes in both cytosolic and nuclear receptors. Similarly, in spite of the presence of androgen receptors in the pituitary, no changes in plasma $\mathrm{LH}$ were observed in ewes after a $1 \mathrm{mg}$ injection of $5 \alpha$-DHT (Clarke, Mitchelhill, Zachariah, Findlay \& Funder, 1982). Furthermore, there is no evidence, under natural conditions, that a testosterone pulse inhibits LH secretion because in June, when pulsatility is high in our breed of rams, a new LH pulse often begins while the plasma testosterone value is close to maximum (Pelletier et al., 1982). These considerations and the shortness of the binding to pituitary nuclei could indicate a non-genomic effect according to McEwen, Krey \& Luyne (1978). However, at present it remains possible that under natural conditions testosterone binding to pituitary nuclei has a genomic effect too discrete to be identified. The injection of $100 \mu \mathrm{g}$ oestradiol to ovariectomized ewes induces a decrease of plasma $\mathrm{LH}$ and FSH which suggests the occurrence of post-nuclear events as discussed by Clarke et al. (1982).

In conclusion, the present study shows that variations in nuclear $\left[{ }^{3} \mathrm{H}\right] \mathrm{DHT}$ receptors are related to a previous increase in plasma testosterone concentrations and indicates a subtle relationship between individual testosterone pulses and the pituitary.

We thank Odile Moulin for her skilful technical assistance and Alice Daifuku for help in the translation of the manuscript.

\section{References}

Blondeau, J.P., Corpechot, C., Le Goascogne, C., Baulieu, E.E. \& Robel, P. (1975) Androgen receptors in the rat ventral prostate and their hormonal control. Vitams Horm. 33, 319-345.

Bradford, M. (1976) A rapid and sensitive method for the quantitation of microgram quantities of protein utilizing the principle of protein-dye binding. Analyt. Biochem. 72, 248-254.

Clark, J.H. \& Peck, E.J. (1979) Female sex steroids. Receptors and function. Monographs on Endocrinology 14, 1-245.

Clarke, I.J., Funder, J.W. \& Findlay, J.K. (1982) Relationship between pituitary nuclear oestrogen receptors and the release of $\mathbf{L H}$, FSH and prolactin in the ewe. J. Reprod. Fert. 64, 355-362.

Clarke, I.J., Mitchelhill, K., Zachariah, E., Findlay, J.K. \& Funder, J.W. (1982) Analysis of androgen actions on pituitary gonadotropin and prolactin secretion in ewes. Biol. Reprod. 26, 777-786.

Corker, C.S., Exley, D. \& Naftolin, F. (1970) Assay of $17 \beta$ estradiol by competitive protein binding methods. Acta endocr., Copenh., Suppl. 147, 305-316.

D'Occhio, M.J., Schanbacher, B.D. \& Kinder, D.E. (1982) Relationship between serum testosterone concentration and patterns of luteinizing hormone secretion in male sheep. Endocrinology 110, 1547-1553. 
Garnier, D.H., Cotta, Y. \& Terqui, M. (1978) Androgen radioimmunoassay in the ram: results of direct plasma testosterone and dehydroepiandrosterone measurement and physiological evaluation. Annls Biol. anim. Biochim. Biophys. 18, 265-281.

King, W.J. \& Greene, G.L. (1984) Monoclonal antibodies localize oestrogen receptor in the nuclei of target cells. Nature, Lond. 307, 745-747.

Lowry, O.H., Rosebrough, N.J., Farr, A.L. \& Randall, R.J. (1951) Protein measurement with the Folin phenol reagent. J. biol. Chem. 193, 265-275.

McEwen, B.S., Krey, L.C. \& Luyne, V.N. (1978) Steroid hormone action in the neuroendocrine system: when is the genome involved? In The Hypothalamus, pp. 255-268. Eds S. Reichlin, R. J. Baldessarini \& J. B. Martin. Raven Press, New York.

Pelletier, J. (1970) Mode of action of testosterone propionate on the secretion and release of luteinizing hormone (LH) in the castrated ram. Acta endocr., Copenh. 63, 290-298.

Pelletier, J. (1974) Decrease in the pituitary response to synthetic LH-RF in castrated rams following testosterone propionate treatment. J. Reprod. Fert. 41, 397-402.

Pelletier, J., Garnier, D.H., de Reviers, M.M., Terqui, M. \& Ortavant, R. (1982) Seasonal variation in LH and testosterone release in rams of two breeds. J. Reprod. Fert. 64, 341-346.

Pelletier, J., Kann, G., Dolais, J. \& Rosselin, G. (1968) Dosage radioimmunologique de l'hormone luteinisante plasmatique chez le mouton. Mise au point de la technique de dosage. C. r. hebd. Séanc. Acad. Sci. Paris D 266, 2291-2294.

Roy, E.J. \& McEwen, B. (1977) An exchange assay for oestrogen receptors in cell nuclei of the adult rat brain. Steroids 30, 657-669.

Scatchard, G. (1949) The attractions of proteins for small molecules and ions. Annls N.Y. Acad. Sci. 51, $660-672$.

Terqui, M., Garnier, D.H., de Reviers, M.M., Huet, S. \& Pelletier, J. (1980) La structure chronologique du dialogue entre l'hypophyse et les gonades chez les mammifères domestiques. In Rythmes et Reproduction, pp. 59-72. Eds R. Ortavant \& A. Reinberg. Masson, Paris.

Thieulant, M.L. \& Pelletier, J. (1979) Evidence for androgen and estrogen receptors in castrated ram pituitary cytosol: influence of time after castration. J. Steroid Biochem. 10, 677-687.

Welshons, W.V., Lieberman, M.E. \& Gorski, J. (1984) Nuclear localization of unoccupied oestrogen receptors. Nature, Lond. 307, 747-749.

Widnell, C.C. \& Tata, J.R. (1964) A procedure for the isolation of enzymically active rat liver nuclei. Biochem. J. 92, 313-317.

Zava, D.T., Harrington, N.Y. \& McGuire, W.L. (1976) Nuclear estradiol receptor in the adult rat uterus: a new exchange assay. Biochemistry, N.Y. 15, $4292-4297$.

Received 31 December 1984 